35. Rudnyts'ka, N. V. (2001). Do istoriyi Zhytomyrs'koho yevreys'koho vchytel's'koho instytutu (1873-1885 rr.) [To the history of Zhytomyr Jewish Teachers' Institute (1873-1885)]. Istoriya Ukrayiny, 37, 8-10.

36. Ryabovol, L. T. (2001). Rozvytok zems'koyi osvity v Khersons'kiy huberniyi (druha polovyna XIX - pochatok XX st.) [Development of rural education in the Kherson province (second half of the XIX - early XX centuries)] : Avtoref. dys. ... kand. ped. nauk: 13.00.01 / Kryvoriz'kyy derzhpedinstytut. Kryvyy Rih.

37. Suchkov, I. V. (1995). Uchitel'stvo Rossii v kontse XIX - nachale XX vv. [The teaching of Russia in the late XIX and early XX centuries] : Dis. ... d-ra ist. nauk: 13.00.01; 07.00.02 / Moskovskiy gospedinstitut. Moskva.

38. Khomych, L. O. (1998). Profesiyno-pedahohichna pidhotovka vchytelya pochatkovykh klasiv [Vocational-pedagogical preparation of elementary school teachers]. Kyiv : Mahister-S, 1998.

39. Ship, N. A. (1991). Intelligentsiya na Ukraine (XX st.): istoriko-sotsial'nyy ocherk [Intellectuals in Ukraine (XX century): a historical and social essay]. Kiyev : Naukova dumka.

УДК [94(477):338.22] «1900/1914»

\title{
ПРИБАЛТІЙСЬКИЙ ПАЛИВНИЙ РИНОК: СПРОБИ ЙОГО ЗАВОЮВАННЯ ДОНЕЦЬКИМ ВУГІЛЛЯМ НА ПОЧАТКУ ХХ ст.
}

\section{Шандра Ірина}

У статті досліджується спроба завоювання прибалтійського паливного ринку донецьким вугіллям на початку XX cm., проаналізовано головні напрями доставки кам'яного вугілля з Донбасу до прибалтійських споживачів (залізничне сполучення, морські перевезення довкола Європи, Дніпровсько-Двінський водний канал). Дослідження базується на загальнонаукових $і$ спеціально-історичних методах (статистичний, порівняльноісторичний, ретроспективний тощсо); в його основу покладено міждисииплінарний і корпоративістський підходи.

На основі діловодної документаиії представницьких організацій підприємиів, матеріалів періодичних видань, урядових розпоряджень у статті показано, що добувна спроможність донецької кам'яновугільної промисловості на початку XX $\mathrm{cm}$. значно переважала наявний попит. Охарактеризовано особливості прибалтійського паливного ринку (залежність від англійського палива, взаємопов'язаність вугільного імпорту та хлібного експорту в Північно-Західному краї). Простежено еволюиію поглядів державних діячів щңодо заміни донецьким вугіллям англійського 
в портах Балтійського моря від економічної доиільності до питань загальнодержавної безпеки. Висвітлено необхідні для залізничних поставок донецького палива складники (зниження тарифів, будівництво додаткових залізничних гілок та забезпечення мережі вантажними вагонами), виділено морський спосіб перевезення як найбільш вірогідний, акиентовано увагу на масштабному проекті річкового сполучення між Чорним $і$ Балтійським морями - водний шлях Херсон-Рига.

Попри нереалізованість задуму із завоювання донеиьким вугіллям прибалтійського паливного ринку на початку ХХ $\mathrm{cm}$., розроблені підприємиями напрями економічних вдосконалень стали наочним свідченням їхньої згуртованості, стратегічного бачення можливих шляхів розвитку регіону. Тому становитиме науковий і практичний інтерес звернення до історичного досвіду економічної взаємодії (або розроблених проектів) в ЧорноморськоБалтійському регіоні, подальше вивчення взаємовигідних економічних проектів між Україною та країнами Прибалтики.

Ключові слова: кам'яне вугілля, прибалтійський паливний ринок, Донбас, З’їзд гірничопромисловиів Півдня Росї̈.

Доставка вугілля з донецьких копалень через Гібралтарську протоку в порти Балтійського моря - мета, «гідна Кромвеля».

Г. фон Шульце-Геверниць

(проф. Фрейбурзького університету, 1901 р.)

Для сучасної України все більш актуальним постає питання поглиблення політичного та економічного співробітництва 3 прибалтійськими країнами, які продемонстрували непорушну відданість стандартам міжнародного права i європейським демократичним цінностям. Національним інститутом стратегічних досліджень спільно 3 Міжнародним центром балтійськочорноморських досліджень та консенсусних практик 23 лютого 2018 р. в Києві був проведений IV Балтійсько-Чорноморський форум «Солідарна безпека країн балтійсько-чорноморського регіону як консенсусна стратегія для Великої Свропи» за участі державних діячів найвищих рангів Білорусі, Болгарії, Естонії, Латвії, Молдови, Польщі, Румунії, Словаччини, України та інших країн. Усі учасники конференції засвідчили підтримку тези про непорушність державних кордонів, миру та поступального економічного розвитку країн Балтійсько-Чорноморського регіону. У цьому широкому контексті стратегічного співробітництва держав-учасниць форуму становитиме інтерес звернення до історії економічних зв'язків між Україною та прибалтійськими країнами, виокремлення тих методів i форм економічного розвитку, які не були використані в минулому та можуть стати в нагоді для сучасної розбудови ефективного економічного співробітництва. 
На початку XX ст. гірничопромисловці Донбасу активно шукали нові ринки збуту палива, адже темпи видобутку вугілля в регіоні були найвищими в світі і значно переважали наявний попит. Цей підприємницький намір зіткнувся з багатьма вадами економіки тодішньої Російської імперії: вузькою місткістю внутрішнього ринку, низьким рівнем пропускної та провізної спроможності залізниць, недостатньою розвиненістю їхньої мережі, відсутністю власного торгового флоту, а головне - консервативністю монархічно-бюрократичного апарату управління, інертного до нових проектів та економічних завдань. Більшість із запропонованих підприємцями нововведень так і залишилися нездійсненими, проте напрацьовані на початку $\mathrm{XX}$ ст. технічні обгрунтування та економічні розрахунки яскраво переконують у значному $\mathrm{i}$, на жаль, дотепер не повною мірою використаному потенціалі співробітництва між країнами балтійсько-чорноморського регіону.

Тема економічного співробітництва українських та прибалтійських земель в історичній ретроспективі розглядається в працях вітчизняних науковців. У монографіях «Сільське господарство України i світовий продовольчий ринок (1861-1914 pp.)» і «Перша світова війна і Україна» (автори О. П. Реєнт, О.В. Сердюк) на основі численних опублікованих i архівних джерел показано певні аспекти економічних зв'язків між регіонами Російської імперії $[17 ; 18]$. Проблеми водних шляхів сполучення та розвиток каботажу між морями Російської імперії наприкінці XIX - на початку XX ст. всебічно досліджено в праці проф. О. Б. Шляхова «Судновласники і моряки Азово-Чорноморського басейну» [32]. Поставки донецького вугілля до прибалтійських споживачів якщо і розглядались у науковій літературі, то як один із складників більш широких тем соціально-економічного розвитку українських земель у другій половині XIX - на початку XX ст. Питання постачання донецького мінерального палива до Прибалтики на початку XX ст. у вітчизняній історіографії не було предметом спеціального дослідження. Так само і розвиток шляхів сполучення між українськими i прибалтійськими губерніями не відтворено в спеціальних розвідках.

Як приклад підприємницької ініціативи й наполегливості, економічної фаховості й технічної підготовленості гірничопромисловців Донбасу становитиме науковий інтерес дослідження спроб завоювання прибалтійського паливного ринку донецьким вугіллям на початку XX ст.

Проблема масових поставок донецького вугілля до Прибалтики, а також витіснення звідти іноземного вугілля стає незмінною темою обговорення на з'їздах гірничопромисловців Півдня Росії, що відтворено в їхній опублікованій діловодній документації (численних «Трудах...», «Отчетах...», «Докладах...»). Ця група джерел відзначається повнотою, точністю й скрупульозністю поданих відомостей, значною кількістю спеціалістів (із залізничного транспорту, водних шляхів сполучення, податкових i митних питань, технічного проектування), залучених для розробки практичних заходів щодо налагодження регулярних поставок донецького вугілля до 
Північно-Західного краю імперії. В обласних архівосховищах у фондах адміністративних державних установ збереглися матеріали клопотань, обгрунтувань і звернень, які готували гірничопромисловці для роз'яснення своїх намірів.

Витіснення англійського вугілля 3 паливного ринку Прибалтики стає помітною темою періодичних видань імперського часу. На початку XX ст. на сторінках журналів «Торгово-промышленный Юг» (м. Одеса, друкований орган Ради 3'їздів представників промисловості й торгівлі Півдня Росії), «Горно-заводское дело» (м. Харків, друкований орган Ради 3'їздів гірничопромисловців Півдня Росії) зустрічаємо висвітлення фактичних даних щодо урядових заходів із зазначеної проблеми або спеціальні аналітичні статті, у яких відображено позицію різних груп буржуазії стосовно вивозу донецького палива до Північно-Західного краю. Видання «Промышленность и торговля» (м. Санкт-Петербург), як орган Загальноімперських з'їздів представників промисловості й торгівлі, намагалося обмежитися сухою констатацією фактів про зміни на паливному ринку, оприлюднюючи урядові нововведення щодо залізничних тарифів і митного обкладення. Питання водних перевезень донецького вугілля в порти Балтійського моря представлено нечисленними, проте грунтовними й об'ємними статтями в журналі «Русское судоходство». Інженери А. Одинцов та В. Чернишов підготували розлогі огляди, у яких змогли майстерно поєднати економічні й технічні розрахунки із макроекономічним аналізом [13; 30]. Використання в комплексі всіх наведених видів джерел дає змогу всебічно розглянути порушену проблему, висвітлити бачення гірничопромисловців Донбасу, підприємців Північно-Західного району, судновласників Чорноморсько-Азовського басейну, дніпровських судновласників, урядовців та решти зацікавлених учасників масових поставок донецького палива до Прибалтійського району на початку XX ст.

\section{Потужність Донецького кам'яновугільного басейну й особливості кон'юнктури прибалтійського ринку}

До 1884 р. ввіз до Російської імперії іноземного кам'яного вугілля був безмитним (тільки на західному сухопутному кордоні мито становило 0,5 коп. $з$ пуда). Такий стан речей був об'єктивним і пов'язаний із низьким видобутком вугілля в імперії: на 1880 р. власний видобуток у цілому по країні становив 200,8 млн пудів, а імпорт - 115 млн пудів [4, 4]. Залізний та паливний ринки знаходились у залежності від іноземного імпорту: у Західному краї домбровське вугілля зустрічало гостру конкуренцію 3 німецьким, а в Прибалтійському районі - 3 англійським.

3 80-х pp. XIX ст. почався період митного заступництва: було встановлено ввізні ставки на іноземне вугілля для Азовсько-Чорноморського басейну (3 коп.) та по західному сухопутному кордону їх було підвищено до 1,5 коп. 3 пуда. За наступні 20 років відбувся суттєвий поворот на користь розвитку Південного економічного району та його природних багатств: активне 
залізничне будівництво, роботи над облаштуванням портів Чорного й Азовського морів, паровий кам'яновугільний каботаж, залучення іноземних капіталів тощо. Державні замовлення на вугілля та метал разом із протекційною митною політикою уряду значно розширили потенційні можливості Південного паливно-металургійного комплексу. У 1904 р. видобуток вугілля в Донбасі досяг 804 млн пудів, тоді як вивіз - 583 млн пудів. У 1908 р. при видобутку 1115 млн пудів вивіз становив 855 млн пудів; 1913 р. видобуток зріс до 1561 млн пудів, вивіз - 1197 млн пудів [1, 9]. За час з 1893 по 1913 рр. видобуток мінерального палива в Донбасі збільшився в 6,5 разів, тоді як аналогічний світовий показник - тільки в 2,5 рази [25, 16-17]. Добувна спроможність донецької кам'яновугільної промисловості наприкінці XIX - на початку XX ст. значно перевищувала об'єми реального видобутку, з великим надлишком могла задовольнити весь наявний попит на мінеральне паливо [24, 23].

Розвиток донецької кам'яновугільної промисловості у свою чергу викликав позитивні зміни в економіці імперії: значно збільшився власний каботаж, зменшилась кількість іноземних зафрахтованих суден, масовість вугільних перевезень підвищила прибутковість залізниць та їхню протяжність як таку. Гірничопромисловці спрямовували численні клопотання до уряду щодо розширення ринків збуту донецького вугілля, завоювання нових внутрішніх ринків $[11,2 ; 12,2]$. Витіснення іноземного палива донецьким у Південному та Південно-Західному економічних районах на початок XX ст. стало доконаним фактом, чого не можна було сказати про Прибалтійський край.

У 80-90-х pp. ХІХ ст. заміна іноземного палива повною мірою донецьким вугіллям в Прибалтиці вважалася справою нездійсненною. Враховуючи наявні об'єктивні фактори (відсутність високоефективних шляхів залізничної та морської доставки донецького вугілля) та десятиліттями складені економічні відносини в Північно-Західному районі імперії, було залишено незмінним фіскальне мито на вугілля в розмірі 0,5 коп. $[27,70]$. Гірничопромисловці Південного економічного району та судновласники Чорноморсько-Азовського басейну клопотали про підвищення мита на ввізне вугілля, проте ці звернення підприємців не отримували урядової підтримки $[21,16-17 ; 20,13]$. Міністерство торгівлі й промисловості зауважувало, що «це питання дуже складне й делікатне, тому що будь-яка спроба вирішення його шляхом підняття мита зустріне найнаполегливіший супротив 3 боку промисловців прибалтійського району» $[15,89]$.

У 1902 р. міністр фінансів С. Ю. Вітте звернувся до XXVI з'їзду гірничопромисловців Півдня Росії із запитом: «Чим можна пояснити таке явище, що в той час, коли [донецька] кам'яновугільна промисловість заявляє про недостатність ринків збуту, до Прибалтійського краю завозиться близько 186 млн пудів іноземного вугілля»? Відповідь представницької корпорації підприємців була сповнена тактовності, а роз'яснення містили й таке судження - «ввезення іноземного вугілля в Балтійський район - факт 
непорушний без докорінної руйнації існуючої системи тарифів митних i залізничних» $[4,9]$. Разом з тим, серед причин такої ситуації гірничопромисловці відмічали недостатність провізної і пропускної спроможності залізниць, низьку розгалуженість їхньої мережі, а також численні недоліки Маріупольського порту, відсутність у південних портах вантажних кораблів великої тоннажності для морських перевезень.

Поряд із об'єктивно існуючими факторами, поширеною була думка, що привіз англійського вугілля до балтійських портів має безпосередній позитивний вплив на вивіз хліба, а заміна іноземного вугілля донецьким (тобто припинення імпорту англійського вугілля) призведе до відсутності дешевих фрахтів для вивозу товарів землеробства. Витіснення англійського вугілля з балтійських портів навіть вважалося справою «досить шкідливою для торгівлі й судноплавства», адже це призвело б до скорочення портових зборів, зменшення кількості іноземних зафрахтованих суден для експорту власних товарів. Гірничопромисловці спростовували цю тезу, наводячи численні приклади непов'язаних між собою коливань на хлібному та вугільному ринках у портах Чорного моря, вказуючи на дію інших факторів, які мали вплив на експорт хліба (розвиненість залізничної мережі та регулярність підвозу хліба до портів; наявність хлібних елеваторів тощо). Досвід Південного економічного району наочно демонстрував, що зі скороченням ввозу іноземного вугілля, скорочення експорту хліба 3 південних портів не відбулося, натомість значно пожвавилося власне судноплавство $[22,44]$. На II з'їзді судновласників Чорноморсько-Азовського району в Одесі прозвучала підтримка тези про заміну іноземного вугілля донецьким у Північно-Західному районі імперії, а ця справа була визначена як «нагальна у зв'язку з розвитком російського вантажного флоту далекого плавання» $[7,556]$.

У другій половині 90-х pp. XIX ст. же з міркувань державної оборони порушувалося питання про заміну іноземного вугілля донецьким для потреб балтійського військового флоту й воєнних заводів $[23,46]$. Результати таких заходів виявилися вдалими і з точки зору якості вугілля, і самої можливості транспортних поставок. Прихильники цих нововведень наводили приклади західноєвропейських держав, де військовий флот постачався й розбудовувався 3 урахуванням особливостей палива тільки власного видобутку (Німеччина, Франція, Велика Британія). На з'їздах підприємців звучали такі думки: «Величезні суми, сплачувані тепер за англійське вугілля, $\epsilon$ настільки великими, що якби казні довелося попервах, враховуючи новизну справи - постачання Північно-Західного краю, переплачувати 3-4 копійки за [донецьке] вугілля, то ця жертва була б мізерною порівняно з величезними сумами, які сплачуються за вугілля англійське» $[4,83]$.

На початку XX ст. питання постачання донецького палива до прибалтійських споживачів усе більше розглядалося можновладцями в ракурсі не стільки економічної доцільності, скільки в контексті питань державної безпеки. 
У квітні 1904 р. для вивчення Ризького кам'яновугільного ринку було відряджено старшого маклера Харківської кам'яновугільної біржі М. Мінаєва. Зі свого боку Ризький біржовий комітет теж проявив цікавість до донецького палива, адже використання англійського вугілля змушувало заводчиків закуповувати його вже влітку й утримувати значні складські приміщення, що було пов'язано з додатковими витратами. Результатом проведених перемовин стала згода ризького торгового дому «Герман Штіде», «Балтійського вагонного заводу» та акціонерного «Товариства Ризького сталеливарного заводу» придбати кілька вагонів донецького вугілля для експериментального використання.

У червні 1904 р. при Головному управлінні торгового мореплавства й портів було утворено Особливу нараду для розгляду питання «про заміну іноземного вугілля власним у Північно-Західному районі імперії» під головуванням М. Лішина. На нараді були порушені такі питання: якісне співвідношення донецького та іноземного вугілля; умови доставки донецького мінерального палива до Прибалтики; урядові заходи, що мають сприяти таким перевезенням; економічний вплив такої заміни на інші сфери економіки. У відповідь на окреслені проблеми підприємці Донецького басейну наголошували на значному перевищенні можливого видобутку над потребами наявних ринків збуту. Так, на 1905 р. Статистичне бюро Ради 3'іздів гірничопромисловців Півдня Росії надавало такі дані: видобувна спроможність кам'яновугільних копалень - 1,3 млрд пудів, а наявний видобуток - лише 951 млн пудів [4, 12]. Щодо якості донецького вугілля, то гірничопромисловці зазначали, що «відповідь на це питання буде настільки ж позитивною, як i на питання про кількість» [4, 17]. За оцінкою проф. Д. І. Менделєєва «за різноманітністю сортів кам'яного вугілля, за багатством прекрасного металургійного вугілля, - напівантрацитів і антрацитів, - Донецький край $є$ найбагатшим у світі родовищем вугілля» $[9,427]$.

У січні 1911 р. відбулося засідання комісії під головуванням товариша міністра торгівлі й промисловості П. І. Міллера за участі представницьких організацій підприємців щодо заміни іноземного вугілля донецьким у портах Балтійського моря [6, 1659]. Комісія одноголосно дійшла висновку, що за технічними показниками донецьке вугілля й антрацит можуть вповні замінити всі сорти англійського вугілля. Підприємці особливо відмітили той факт, що протягом поточного року Міністерство торгівлі й промисловості закупило у фірм Донецького басейну 500 тис. пудів кам'яного вугілля замість використовуваного раніше англійського. Причому донецьке вугілля під час випробувань виявилося більш пароутворюючим порівняно 3 англійським, а тому було визнано економнішим [16, 8-9]. На 1912 р. Міністерство торгівлі й промисловості внесло в кошторис додатковий кредит у розмірі 70 тис. руб. для заміни англійського вугілля донецьким у портах Балтійського моря $[19,3106]$. 
Упевнившись у достатній кількості й належній якості донецького вугілля, а також враховуючи фактор державної оборони та необхідність покращення торгового балансу країни й розвитку власного торгового флоту, перед урядовцями та підприємцями постало питання про можливі шляхи його транспортування до прибалтійських споживачів. Розроблялися три можливі варіанти доставки: 1) прямий залізничний; 2) морський довкола Європи з Азовського й Чорного морів у Балтійське; 3) внутрішні водні шляхи.

\section{Доставка донецького вугілля в Прибалтику залізничним сполученням}

Один із головних складників успіху конкуренції донецького вугілля 3 англійським і вестфальським у Північно-Західному районі полягав у зниженні вартості доставки залізничним сполученням. Гірничопромисловці зверталися до уряду із численними клопотаннями ліквідувати «перепону для збуту нашого вугілля», «усунути таку ненормальність» шляхом запровадження захисних митних ставок на ввізне вугілля, а також зменшити залізничні тарифи для доставки донецького вугілля до Прибалтійського краю. У такий спосіб підприємці сподівалися «боронити нашу ще молоду промисловість від того сильного тиску іноземної конкуренції, який підриває справу в іiі зародку і до того ж за допомогою наших же, урядом облаштованих і гарантованих залізниць» [3, 19-20].

Питома вага іноземного вугілля й коксу, ввезеного в прибалтійські порти, на початку XX ст. складала близько 70 \% загального ввозу: у 1895 р. 105 млн пудів (76 \%), у 1900 р. - 170 (71\%), у 1903 р. - $145(70 \%)$ [4, 128]. Левова частка завезеного палива залишалася власне у портових містах, обсяг вивозу вглиб країни був мізерним.

Вивчення умов транспортування вугілля з Донбасу до Прибалтики було проведено головою Харківського комітету з перевезень гірничозаводських вантажів В.А. Гаєвським, начальником комерційного відділу ЛозовоКиївської залізниці $Є$. А. Могиленським, спеціальні обговорення цього питання були проведені на XXIX з'їзді гірничопромисловців Півдня Росії в Харкові (1904р.). Доповідачі пропонували такий підхід до розв'язання проблеми. Перш за все, зниження залізничних тарифів до 1/150 коп. 3 пудаверсти, що мало б дати здешевлення витрат за пуд вугілля 3 центральних станцій Донбасу до Санкт-Петербурга в середньому на 3 коп. Такий крок мав би зробити донецьке вугілля більш вигідним паливом для споживачів, які зв'язані коліями з Невськими пристанями. Є. Могиленський застерігав, що передбачуваний обсяг перевезень навряд чи можливий через недостатню пропускну спроможність найкоротшого залізничного шляху на Прибалтику через Куп'янськ-Курськ-Москву, який і так перевантажений. Як вихід із ситуації було запропоновано клопотати про будівництво нового залізничного сполучення між Донбасом та Прибалтикою не довше ніж наявне, проте «працездатне й вільне». Цей напрям планували прокласти через 
Артакове-Брянськ-Вітебськ. На вказаному відрізку слід було побудувати додаткову залізничну гілку від однієї з центральних станцій Донбасу до Артакового (понад 400 верст), решта шляху, у цілому, відповідала вимогам пропускної спроможності 3 урахуванням введення в експлуатацію вже запланованих магістралей. Реалізація двох наведених умов (додаткові залізничні шляхи й зниження провізних тарифів) мала дати можливість $\mathrm{i}$ управлінням залізниць отримати прибуток (близько 1,4 млн руб.), і донецькому паливу стати конкурентоспроможним на Прибалтійському ринку.

З’їзди гірничопромисловців Півдня Росії ці клопотання до уряду повторювали й на наступних з'їздах. У 1912 p. незмінним залишалося звернення про встановлення зниженого тарифу для транспортування вугілля з усіх станцій Донецького басейну до станцій Прибалтійського району; про посилення пропускної і провізної спроможності доріг усіх напрямів від Донбасу до Балтійського моря [8, 338].

Отже, щоб донецьке вугілля було конкурентоспроможним на Прибалтійському паливному ринку представники південної буржуазії вважали необхідним проведення таких дій: зниження залізничних тарифів від усіх станцій Донбасу до Петербурга, Риги, Лібави, Ревеля й Віндави; будівництво залізниці від станції Попасна до Артакове довжиною близько 400 верст; забезпечення вагонного парку вагонами більшої вантажомісткості.

\section{Морське перевезення донецького вугілля}

\section{з Азовського та Чорного морів у Балтійське}

3 усіх варіантів можливої доставки донецького вугілля в Прибалтику саме розвиток морського каботажу вважався найреальнішим інструментом боротьби за Північно-Західний паливний ринок. Такий спосіб не порушував наявних інтересів промисловців Прибалтійського району та тяжіючих до нього експортерів. Дальність відстані тільки на перший погляд робила цю справу вкрай складною, але за умови продуманих рейсів донецьке вугілля успішно конкурувало б з іноземним у портах Балтійського моря. На зворотному шляху судна могли перевозити хліб, льон, пеньку (навіть англійське вугілля аж до Константинополя), що дало б можливість знизити фрахти до найнижчого рівня.

Розгляд морського варіанту перевезення донецького вугілля загострював проблему благоустрою портів, питання їхньої глибини й рівня механізації, а також загальні умови розвитку морського сполучення. Гірничопромисловці наголошували, що кам'яне вугілля $є$ вантажем «малоцінним», тому такий товар доцільно перевозити суднами великої вантажомісткості та масовим способом (як приклад, наводився успішний досвід Великої Британії щодо створення комерційного флоту). У зв'язку з цим урядовцям пропонувалося створити умови для формування торгового флоту між морями Російської імперії, «не соромлячись вживати найрадикальніші заходи щодо захисту 
власного флоту від конкуренції з іноземним... Це тимчасове обтяження перетвориться на благо і для держави, і для населення» [4, 41-42].

Маріупольський порт був об'єктивно головним портом для вивозу донецького палива. Первинно він був облаштований з невеликою глибиною, слугував переважно потребам каботажу в межах Азовсько-Чорноморського басейну. 3 часом його значення посилилося для експорту не тільки вугілля, але й хліба, заліза, продуктів хімічної промисловості тощо. Для залучення Маріупольського порту до намірів із завоювання донецьким вугіллям Прибалтійського району, перш за все, його варто було поглибити до 26 футів (при 14 наявних), а глибину Керченської протоки довести до 28 футів [4, 43]. Проблему замерзання Маріупольського порту планувалося частково вирішити за допомогою криголаму. У якості незамерзаючого порту на Чорному морі було розглянуто Скадовськ, накреслено перспективи будівництва Скадовської залізниці, яка мала б з'єднати Донецький кам'яновугільний басейн 3 портом. Також підприємці порушили клопотання про додаткове фінансування Феодосійського порту як найближчого до Донбасу незамерзаючого порту.

Серед необхідних умов для розвитку «великого вугільного каботажу» (між Чорним і Азовським та Балтійським морями) підприємці виділяли такі: на законодавчому рівні зробити обов'язковим споживання донецького вугілля для Балтійського військового флоту й усіх казенних підприємств Північно-Західного краю; встановити премію для судновласників, які здійснюють транспортування кам'яного вугілля 3 портів Чорного й Азовського морів до Балтійського узбережжя («каботажна премія») [4, 49]. Усі ці заходи вимагали від уряду додаткових початкових витрат та послідовної економічної політики, спрямованої на розвиток власної підприємницької активності.

\section{Внутрішні водні шляхи сполучення}

На початку XX ст., первинно у середовищі промисловців та підприємців, а пізніше і в урядових колах, активно обговорювалося питання про створення внутрішньоконтинентального Чорноморсько-Балтійського водного шляху. Особливістю водних шляхів, що вигідно відрізняли їх від залізничного сполучення, була дешевизна транспортування й майже необмежена пропускна спроможність. Завдяки цьому, водні шляхи якнайкраще відповідали завданням перевезення масових вантажів (вугілля, метал, ліс, хліб, цукор тощо). Проте тільки достатньо глибокі та протяжні водні артерії здатні забезпечити більш дешеве, порівняно із залізницями, транспортування. Чим більша глибина водного шляху та вантажомісткість суден, тим менші експлуатаційні витрати з пуда-версти.

Між басейнами Західної Двіни й Дніпра на початку XX ст. вже існував водний шлях - так звана Березинська система (з'єднувальний шлях від р. Березини, що впадає в Дніпро, до Двіни складав 148 верст, мав 14 шлюзів, 
4 греблі). Ця система була побудована в 1804 p. i до початку XX ст. використовувалася переважно для транспортування лісу до Риги. Для судноплавства цей водний шлях був непридатним, а канали й річки, які були дотичними до нього, постійно замулювалися й заростали. Окрім Березинської системи, між Чорним і Балтійським морями було ще кілька водних сполучень (Огинське, Августовське, Дніпровсько-Бузьке). Усі вони були також мілководними, проте головний їхій недолік полягав у тому, що закінчувалися вони на території Німеччини [13, 12].

3 усіх запропонованих на початку XX ст. проектів 3'єднання Чорного та Балтійського морів найбільш економічно і стратегічно доцільним був визнаний Дніпровсько-Двінський варіант: від м. Херсон через р. Дніпро, p. Оршиця, проектований Орша-Вітебський канал, р. Лучеса (притока Західної Двіни), р. Західна Двіна з кінцевим пунктом шляху в м. Рига.

Такий проект водної магістралі підтримали 3'їди гірничопромисловців Півдня Росії, Катеринославське губернське земське зібрання, Херсонська губернська управа, Ризький біржовий комітет та інші громадські й адміністративні установи, а також спеціально скликаний 3'їзд з питань щодо 3'єднання Чорного й Балтійського морів (Київ, 1911 р.) і 3'їзд ПівденноЗахідного краю з питань експорту (Київ, 1914 р.).

Для реалізації проекту на всій протяжності від Херсона до Риги передбачалося проводити такі роботи: обхід порогів на Дніпрі й Західній Двіні шляхом прокладання додаткових каналів, виправні споруди від гирла Березини до Катеринослава, землечерпання й поглиблення скелястого дна в нижній течії Дніпра. Загальна вартість робіт на всій відстані величезного водного шляху протяжністю близько 2300 верст від Херсона до Риги за приблизними підрахунками складала 150 млн руб. Кількість вантажів, які планувалося перевозити цим напрямом щорічно, за мінімальними підрахунками, мала б скласти понад 300 млн пудів [29, 2701]. Річний вантажообіг для Дніпровсько-Двінської системи інженер А. Одинцов передбачав у розмірі 1300 млн пудів [13, 19], а спеціальна комісія 3'їздів гірничопромисловців Півдня Росії у своїх розрахунках наводила цифру 1660 млн пудів [4, 63].

Проект Орша-Вітебського каналу, який входив до системи Херсон-Рига, був складений Управлінням внутрішніх водних сполучень Міністерства шляхів сполучення. Передбачалося, що він становитиме 86 верст у довжину, 14 сажнів у ширину, 10 четвертей аршина в глибину. Вартість будівництва каналу за попередніми розрахунками становила 19 млн руб. [4, 62].

Для всебічного розгляду цього проекту в травні 1911 р. в Києві відбувся 3'їзд з питання з'єднання Чорного й Балтійського морів. У роботі з'їзду брали участь представники всіх зацікавлених відомств і різних галузей промисловості й торгівлі 12 губерній, розташованих у районі передбачуваної водної магістралі. Катеринославське губернське земське зібрання заявило про свою повну підтримку проекту та асигнувало на реалізацію водного 
шляху Херсон-Рига 3000 руб. для проведення дослідницьких робіт в межах Катеринославської губернії [28, 668].

Грандіозний проект Херсон-Рига позначився і на планах дніпровських судновласників. У 1912 р. у пресі з'явилися повідомлення, що місцеві пароплавства готуються до випуску нових акцій на загальну суму мільйон рублів і вже замовили німецькому заводу Круппа нові товарно-пасажирські пароплави $[10,39]$.

Масовими вантажами проектованого водного шляху в північному напрямі мали стати донецьке кам'яне вугілля, криворізькі чавун і сталь, бахмутська й кримська сіль, а також сільськогосподарська продукція (хліб, цукор, конопля, тютюн, лляне насіння, вовна, шкіра та ін.). У південному напрямі по каналу передбачалося переправляти ліс, колоніальні товари, штучні добрива, машини, хімічні продукти тощо. За підрахунками Ризького біржового комітету транспортування водним шляхом Рига-Херсон обходилось би не більше 7-8 коп. 3 пуда (у середньому навіть 5-6 коп. [4, 59]), тоді як фрахти за морські перевезення від Чорного до Балтійського моря складали на кам'яне вугілля 9,25 коп. 3 пуда, для солі - 8-10 коп., для заліза й сталі 11,5-13 коп., для борошна - 13 коп. Морський шлях з Чорноморських портів у порти Балтійського моря довкола Свропи тривав 3,5-4 тижні, водним же шляхом Херсон-Рига тривалість транспортування скорочувалась до 12 днів $[29,2702]$. Отже, водний Дніпровсько-Двінський шлях мав стати більш коротким і дешевим способом міжрегіональної і зовнішньої торгівлі українських, білоруських і прибалтійських земель.

Інженер Одинцов наголошував, що транспортування каналом ХерсонРига приведе до зниження ціни на донецьке вугілля до 15 коп. (у Ризькому порту), що на 5 коп. дешевше англійського. Таким чином, близько 300 млн пудів англійського вугілля, яке щорічно надходило в порти Балтійського моря, буде замінено донецьким вугіллям. Враховуючи серед споживачів донецького палива ще й самі транспортні судна, а також можливий експорт вугілля до Фінляндії та інших країн Скандинавії, обсяг транспортованого по каналу вугілля складав до 400 млн пудів $[13,18]$. Більш того, проектований водний шлях мав сприяти комплексному розвитку цих районів як результат пожвавлення торгових відносин і всіх сприятливих наслідків таких процесів. Товариш голови Ради З'їздів представників промисловості й торгівлі Півдня Росії (м. Одеса) С. І. Соколовський зауважував, що «Балтійсько-Чорноморський канал обіцяє такі грандіозні перспективи для всієї Росії» $[14,48]$.

3 приводу практичної реалізації Дніпровсько-Двінського водного шляху розгорнулись гострі дискусії. Каменем спотикання стало питання «чи бути Чорноморсько-Балтійській магістралі морським шляхом (за різними проектами глибина мала становити від 14 футів до 4,5 сажнів [24 та 54 четвертини відповідно]), чи тільки покращеним річковим (3 осадкою судів до 10 четвертин)» $[30,38]$ ? Підготовка водного шляху як морського, безумовно, була більш фінансово витратною, проте і вантажообіг морського шляху за 
попередніми техніко-економічними розрахунками втричі перевищував би цей показник, ніж у річковому варіанті. Крім потоку вантажів між українськими, білоруськими й прибалтійськими регіонами, місцевого вантажообігу дніпровського й західно-двінського районів, морський варіант шляху міг би пропускати всі ті вантажі, які виходили з портів Азовського і Чорного морів у Балтійське довкола Західної Свропи. Отже, за допомогою морського шляху Херсон-Рига одночасно здійснювались би завдання і внутрішньої, i зовнішньої торгівлі. На з’їзді гірничопромисловців Півдня Росії картина майбутнього водного шляху змальовувалася вкрай оптимістично: «Кожне із розташованих всередині материка міст стане тоді морським портом, здатним реалізовувати товари свого району, отримувати іноземні товари безпосередньо з океанських пароплавів. Увесь канал буде освітлюватися електрикою i тому судна, йдучи i вдень, i вночі, зі швидкістю, яку передбачається допустити до 6 вузлів, увесь шлях по такому каналу можуть пройти за 144 години» [4, 190]. Таким чином, центри експорту були б перенесені вглиб країни.

Інженер В. Чернишов у журналі «Русское судоходство» докладно обгрунтовував, що тільки морський варіант шляху Херсон-Рига зможе змінити існуючий стан речей як «у справі залежності південної Росії від Дарданелл, так і Прибалтійського району від іноземного вугілля» [31, 25]. Ризький біржовий комітет також висловив побажання про дотримання морських стандартів облаштування шляху Херсон-Рига [2, 125]. Старший маклер Харківської кам'яновугільної біржі М. П. Мінаєв у своїй доповіді біржовому товариству зазначав, що цей канал «був би найсприятливішим рішенням для донецької і ризької промисловості й торгівлі» [4, 178]. Проте звучали й критичні думки щодо цього проекту. Як писав харківський проф. П. І. Фомін (секретар кількох з'їдів гірничопромисловців Півдня Росії) 3 посиланням на інженера Фершнера, «водне перевезення буде вигідним лише тоді, коли водні шляхи сполучення підійдуть до самих копалень. Як це не звучить парадоксально, проте це досить виправдано комерційними викладками й калькуляцією собівартості вугілля. Одним словом, найближче майбутнє Донецького басейну не є тісно пов'язаним із проблемою водних шляхів сполучення» $[26,52]$.

Чим довше проект водного сполучення між Чорним і Балтійським морями обговорювався на різноманітних громадських зібраннях і наукових засіданнях, тим більше він визнавався необхідним і невідкладним для виконання. Нарешті, 12 квітня 1912 р. члени Державної думи (44 підписи) внесли на розгляд законопроект про найшвидше будівництво ЧорноморськоБалтійської водної магістралі. Безпосередньою причиною цього подання стало закриття Дарданелл оттоманським урядом і вугільний страйк у Великій Британії. Як наслідок такого force majeure кількість «ревних прихильників» водного шляху Херсон-Рига значно поповнилась. У законопроекті вказувалося, що на початок 1914 р. мав бути складений проект зведення водного 
шляху Херсон-Рига (с осадкою суден 10 четвертин), усі роботи планувалось завершити протягом п'яти років [5, 64].

Усупереч беззаперечним економічним i стратегічним вигодам Дніпровсько-Двінського каналу подальші події світового масштабу не дали можливості здійснити намічений план. Інтерес до проекту «Водний коридор Херсон-Рига» відновився майже сто років по тому - у 2002 р. у засобах масової інформації з'явилися повідомлення про зацікавленість Латвії, Білорусі й України у відновленні робіт над проектом, який би об'єднав басейни Чорного та Балтійського морів.

Початок XX ст. виявився насиченим на політичні події в Російській імперії та масштабні потрясіння світового масштабу. Поступальний розвиток промисловості й торгівлі мирного часу був кинутий на поталу воєнних компаній та ефемерного бажання невиправданих територіальних змін. Запропоновані підприємницькими колами та схвалені урядовцями економічні задуми так i залишилися на папері, а завоювання донецьким вугіллям прибалтійського паливного ринку - лише бажаним результатом розвитку Донбасу. Проект водного шляху Херсон-Рига, який накреслював такі широкі можливості й передбачав максимальну реалізацію потенціалу прилеглих до нього українських, білоруських та латвійських територій, на жаль, лишився тільки прикладом інженерної думки та стратегічного мислення.

Розширення й вдосконалення транспортних сполучень між українськими, білоруськими та прибалтійськими губерніями на початку ХX ст. мало б найсприятливіші наслідки для економічного розвитку цих районів. Лісова торгівля Північно-Західного краю могла б скласти достойну конкуренцію німецькій деревообробній промисловості. Хліб українських чорноземних губерній отримав би зручний вихід до всіх балтійських і взагалі північних портів (зникла б залежність від Дарданелл). Кам'яне вугілля отримало б належний доступ до прибалтійських споживачів (була б знищена залежність від англійських поставок), сам регіон був би забезпечений і більш якісним вугіллям, і стратегічно доцільним способом постачання палива на випадок зовнішньополітичних ускладнень між країнами Європи. Усе це в сукупності привело б до загального розвитку торгового й воєнного флоту, широкого залучення цих регіонів до міжнародної торгівлі. Таким було бачення підприємців і всіх зацікавлених учасників цих проектів.

Вихід товарів власного виробництва на нові ринки - $\epsilon$ запорукою зростання економіки будь-якої країни. Така наполегливість, економічна й технічна підготовленість у просуванні власних економічних ініціатив, яку демонстрували гірничопромисловці та представники інших груп буржуазії на початку XX ст., свідчить про високий рівень розвитку самоорганізації представників великого капіталу й значну ступінь «хисту до підприємництва». Становитиме науковий і практичний інтерес дослідження процесу просування всього асортименту українських товарів як у межах Російської імперії в другій половині XIX - на початку XX ст., так і на закордонних 
ринках. У практично-економічному відношенні цікавим буде використання деяких елементів економічних програм, накреслених на початку XX ст., у новітніх стратегіях розвитку економіки України, звернення до ідеї масштабного проекту водного шляху Херсон-Рига та його додаткове доопрацювання в сучасних реаліях.

\section{Abstract}

The author of this article studies the attempts to conquer the Baltic fuel market by Donetsk coal at the beginning of the 20th century. Author analyzed the main delivery directions of coal from the Donbas to the Baltic consumers (railway, transportations by the sea around the Europe, Dnieper-Dvina Canal). The study on general scientific and special methods of history (statistic, comparative-historical, retrospective etc.) is based; it was used also the interdisciplinary and corporatist approaches.

On the basis of the documentation of representative organizations of entrepreneurs, materials of periodical publications and government orders shows the author of this article that extractive capacity of the Donetsk coal industry at the beginning of the 20-th century significantly prevailed the existing demand. Author described the peculiarities of the Baltic fuel market (dependence on English fuel, interconnection of coal imports and grain exports from the North-West region). It was traced the evolution of the views of statesmen about the replacement of Donetsk coal on English coal in the ports of the Baltic Sea from economic expediency to issues of national security. Author explained the necessary components for the delivery the Donetsk fuel by railway (reduction of tariffs, building of additional railway lines and provision of the railway system by goods carriages), the delivery method by sea is accept as the most probable way. Author is focused the attention on the large-scale project of the river connection of the Black and Baltic Seas - the Kherson-Riga waterway.

Despite the unfulfilled plan of conquest, the Baltic fuel market by Donetsk fuel at the beginning of the 20-th century, the directions of economic improvements that by entrepreneurs were developed became a demonstrative indication of their unity, a strategic vision of possible ways of developing the region. Therefore, it will be of scientific and practical interest to apply to the historical experience of economic interaction (or developed projects) in the Black Sea-Baltic region, the further study of mutually beneficial economic projects between Ukraine and the Baltic States.

Key words: coal, the Baltic fuel market, Donbas, Congresses of Mining Industry of South of Russia.

\section{Аннотация}

В статье исследуется попытка завоевания прибалтийского топливного рынка донецким углем в начале ХХ в., проанализированы главные направления доставки каменного угля с Донбасса к прибалтийским потребителям (железнодорожное сообщение, морские перевозки вокруг Европь, 
Днепровско-Двинский водный канал). Исследование основано на общенаучных и спечиально-исторических методах (статистический, сравнительноисторический, ретроспективный и т. п.); в основу положены междисииплинарный и корпоративистский подходы.

На основе делопроизводственной документаиии представительных организачий предпринимателей, материалов периодических изданий, правительственных распоряжений в статье показано, что добываюшая способность донецкой каменноугольной промышленности в начале ХХв. значительно превосходила имеющийся спрос. Выделень особенности прибалтийского топливного рынка (зависимость от английского топлива, взаимосвязанность угольного импорта и хлебного экспорта в СевероЗападном крае). Прослежена эволюиия взглядов государственных деятелей относительно замень донечким углем английского в портах Балтийского моря от экономической иелесообразности к вопросам общегосударственной безопасности. Освещены необходимые для железнодорожных поставок донецкого угля составляюшие (понижение тарифов, строительство дополнительных железнодорожных линий и обеспечение сети грузовыми вагонами), выделен морской способ перевозки как наиболее вероятный, акцентировано внимание на масштабном проекте речного сообщения между Черным и Балтийским морями - водный путь Херсон-Рига.

Вопреки нереализованности замысла по завоеванию донецким углем прибалтийского топливного рынка в начале XX в., разработанные предпринимателями направления экономических усовершенствований стали явным свидетельством их сплоченности, стратегического видения возможных путей развития региона. Поэтому составляет научный и практический интерес обращение к историческому опыту экономического взаимодействия (или разработанных проектов) в Черноморско-Балтийском регионе, дальнейшее изучение взаимовыгодных экономических проектов между Украиной и странами Прибалтики.

Ключевые слова: каменный уголь, прибалтийский топливный рынок, Донбасс, Съезды горнопромышленников Юга России.

\section{ДЖЕРЕЛА ТА ЛІТЕРАТУРА}

1. Арский Р. Донецкий бассейн. Москва : Б. и., 1918. 47 с.

2. Водный путь Рига-Херсон. Русское судоходство. 1911. № 8. С. 123-126.

3. Дело о съезде горнопромышленников Юга России в г. Харькове в 1881 г. Держархів Ростовської області (РФ). Ф. 32. Оп. 1. Спр. 707. 13 арк.

4. Доклад комиссии XXIX Съезду горнопромышленников Юга России по 3-му, 4-му и 5-му вопросам программы: «О современном положении каменноугольной промышленности юга России», «О мерах распространения русского каменного угля в портах Балтийского моря», «О выработке торговых марок русского угля по образцу английских углей». Харьков : Тип. и Литогр. М. Зильберберг и С-вья, 1904. [разд. паг.]. 
5. Законодательные учреждения по вопросам промышленности и торговли. Торгово-промышленный Юг. 1912. № 11. С. 62-65.

6. Заседание Междуведомственной комиссии о замене иностранного угля русским в Прибалтийском районе. Горно-заводское дело. 1911. № 4. C. 1659 .

7. Из деятельности общественных учреждений по промышленности и торговле. Промышленность и торговля. 1910. № 22. С. 556-558.

8. Каменноугольное дело. Промышленность и торговля. 1912. № 6. С. 338.

9. Менделеев Д. И. Проблемы экономического развития России. Москва : Изд-во соц.-экон. лит-ры, 1960. 615 с.

10. Наше судоходство. Русское судоходство. 1912. № 9. С. 39-40.

11. O XVI съезде горнопромышленников в г. Харькове. Держархів Харківської області. Ф. 45. Оп. 1. Спр. 1697. 3 арк.

12. О XX съезде горнопромышленников в г. Харькове. Держархів Харківської області. Ф. 45. Оп. 1. Спр. 2109. 4 арк.

13. Одинцов А. Балтийско-Черноморский водный путь. Русское судоходство. 1914. № 8. С. 11-19.

14. Отчет об экономическом совещании представителей промышленности и торговли Юга России 14 февраля 1916 года. Торгово-промыишленный Юг. 1916. № 4. С. 35-58.

15. Отчет Совета Съезда XXXV съезду горнопромышленников Юга России за 1909-1910 отчетный год. Т. 2. Харьков : Б. и., 1910. [разд. паг.].

16. Отчет Совета съезда XXXVI съезду горнопромышленников юга России за 1910-1911 отчетный год. Харьков : Тип. Б. Бенгис, 1911. [разд. паг.].

17. Реєнт О., Сердюк О. Перша світова війна і Україна. Київ : Генеза, 2004. $473 \mathrm{c}$.

18. Реєнт О. П., Сердюк О. В. Сільське господарство України і світовий продовольчий ринок (1861-1914 рр.). Київ: Ін-т історії України НАН України, 2011. 365 с.

19. XXXVI съезд горнопромышленников Юга России. Горно-заводское дело. 1911. № 46. С. 3102-3110.

20. Труды III-го съезда судовладельцев Черноморско-Азовского района. Одесса : «Центральная» типография, 1912. [разд. паг.].

21. Труды IX съезда горнопромышленников Юга России. Харьков : Типография К. П. Счасни, 1885. [разд. паг.].

22. Труды XXIX съезда горнопромышленников Юга России. Т. 1. Харьков : Тип. и Литогр. М. Зильберберг и С-вья, 1905. [разд. паг.].

23. Труды XXX съезда горнопромышленников Юга России. Т. II. Харьков : Т-во «Печатня С. П. Яковлева», 1906. [разд. паг.].

24. Труды XXXVII съезда горнопромышленников Юга России. Т. 1. Харьков : Тип. Б. Бенгис, 1913. [разд. паг.].

25. Фомин П. И. Донецкий бассейн. Харьков: Б. и., 1920. 35 с. 
26. Фомин П. И. Горная и горнозаводская промышленность Юга России. Т. II. Харьков : «Хозяйство Донбасса», 1924. 202 с.

27. Фомин П. И. Краткий очерк истории съездов горнопромышленников Юга России. Харьков : Тип. и Литогр. М. Зильберберг и С-вья, 1908. 173 с.

28. Хроника. Промышиленность и торговля. 1910. № 24. С. 668.

29. Черноморско-Балтийский водный путь. Горно-заводское дело. 1911. № 35. C. 2700-2702.

30. Чернышев В. Черноморско-Балтийский водный путь в финансовоэкономическом освещении. Русское судоходство. 1912. № 9. С. 35-39.

31. Чернышев В. Черноморско-Балтийский водный путь в финансовоэкономическом освещении. Русское судоходство. 1912. № 11. С. 23-29.

32. Шляхов О. Б. Судновласники і моряки Азово-Чорноморського басейну: 90-ті pp. ХІХ ст. - 1914 р.: монографія. Дніпропетровськ : Вид-во Дніпропетр. ун-ту, 2003. 366 с.

\section{References}

1. Arskiy, R. (1918). Donetskiy basseyn [Donetsk coal field]. Moskva: B. i.

2. Vodnyu put Riga-Kherson [The Riga-Kherson Waterway]. (1911). Russkoye sudokhodstvo, 8, 123-126.

3. Delo o syezde gornopromyshlennikov Yuga Rossii v g. Kharkove v 1881 g. [The Case of the Congress of Mine-Industrialists of the South of Russia in Kharkiv in 1881]. Derzharkhiv Rostovskoi oblasti (RF). F. 32. Op. 1. Spr. 707.

4. Doklad komissii XXIX Syezdu gornopromyshlennikov Yuga Rossii po 3-mu, 4-mu i 5-mu voprosam programmy: «O sovremennom polozhenii kamennougolnoy promyshlennosti yuga Rossii», «O merakh rasprostraneniya russkogo kamennogo uglia $\mathrm{v}$ portakh Baltiyskogo moria», "O vyrabotke torgovykh marok russkogo uglia po obraztsu angliyskikh ugley» [Report of the XXIX Committee of the Congress of Mine-Industrialists of the South of Russia on the 3rd, 4th and 5th Issues of the Program: "On the Current State of the Coal Industry in the South of Russia», "On Measures for the Spread of Russian Coal in the Ports of the Baltic Sea», "On the Elaboration of Russian Coal Brands in the Form of English Coals»]. (1904). Kharkov: Tip. i Litogr. M. Zilberberg i S-vya.

5. Zakonodatelnyye uchrezhdeniya po voprosam promyshlennosti i tirgovli [Legislative Institutions on Industry and Trade]. (1912). Torgovopromyshlennyu Yug, 11, 62-65.

6. Zasedaniye Mezhduvedomstvennnoy komissii o zamene inostrannogo uglia russkim v Pribaltiyskom rayone [Meeting of the Interdepartmental Committee on the replacement of foreign coal by Russian coal in the Baltic region]. (1911). Gorno-zavodskoye delo, 4, 1659.

7. Iz deyatelnosti obshchestvennykh uchrezhdeniy po promyshlennosti i torgovle [From the activities of public institutions of industry and trade]. (1910). Promyshlennost i torgovlia, 22, 556-558. 
8. Kamennougolnoye delo [Coal-Mining Industry]. (1912). Promyshlennost i torgovlia, 6, 338 .

9. Mendeleyev, D. I. (1960). Problemy ekonomicheskogo razvitiya Rossii [Problems of economic development of Russia]. Moskva : Izd-vo sots.-ekon. lit-ry.

10. Nashe sudokhodstvo [Our Shipping]. (1912). Russkoye sudokhodstvo, 9, 39-40.

11. O XVI syezde gornopromyshlennikov v g. Kharkove [About the XVI Congress of Miners in Kharkiv]. Derzharkhiv Kharkivskoi oblasti. F. 45. Op. 1. Spr. 1697.

12. O XX syezde gornopromyshlennikov v g. Kharkove [About the XX Congress of Miners in Kharkiv]. Derzharkhiv Kharkivskoi oblasti. F. 45. Op. 1. Spr. 2109.

13. Odintsov, A. (1914). Baltiysko-Chernomorskiy vodnyu put [Baltic Sea-Black Sea Waterway]. Russkoye sudokhodstvo, 8, 11-19.

14. Otchet ob ekonomicheskom soveshchanii predstaviteley promyshlennosti i torgovli Yuga Rossii 14 fevralia 1916 goda [Report on the Economic Meeting of Industry and Trade Representatives of the South of Russia on 14-th of February, 1916]. (1916). Torgovo-promyshlennyu Yug, 4, 35-58.

15. Otchet Soveta Syezda XXXV syezdu gornopromyshlennikov Yuga Rossii za 1909-1910 otchetnyu god [Report of the Council of the Congress of the XXXV Congress of Mine-Industrialists in the South of Russia for the period 1909-1910 fiscal years]. (1910). T. 2. Kharkov : B. i.

16. Otchet Soveta syezda XXXVI syezdu gornopromyshlennikov yuga Rossii za 1910-1911 otchetnyu god [Report of the Council of the Congress of the XXXVI Congress of Mine-Industrialists in the South of Russia for the period 1910-1911 fiscal years]. (1911). Kharkov : Tip. B. Bengis.

17. Reient, O., Serdiuk, O. (2004). Persha svitova viyna i Ukraina [World War I and Ukraine]. Kyiv : Geneza.

18. Reient, O. P., Serdiuk, O. V. (2011). Silske gospodarstvo Ukrainy i svitovyi prodovolchii rynok (1861-1914 rr.) [Agriculture of Ukraine and the World Food Market (1861-1914)]. Kyiv : In-t istorii Ukrainy NAN Ukrainy.

19. XXXVI syezd gornopromyshlennikov Yuga Rossii [The XXXVI Congress of Mine-Industrialists on the South of Russia]. (1911). Gorno-zavodskoe delo, 46, 3102-3110.

20. Trudy III-go syezda sudovladeltsev Chernomorsko-Azovskogo rayona [Proceedings of the III-th Congress of Ship-Owners of the Black Sea-Azov Sea region]. (1912). Odessa : «Tsentralnaya» tipografiya.

21. Trudy IX syezda gornopromyshlennikov Yuga Rossii [Proceedings of the IX Congress of Miners of the South of Russia]. (1885). Kharkov: Tipografiya K. P. Schasni.

22. Trudy XXIX syezda gornopromyshlennikov Yuga Rossii [Proceedings of the XXIX Congress of Miners of the South of Russia]. (1905). T. 1. Kharkov: Tip. i Litogr. M. Zilberberg i S-vya. 
23. Trudy XXX syezda gornopromyshlennikov Yuga Rossii [Proceedings of the XXX Congress of Miners of the South of Russia]. (1906). T. II. Kharkov: T-vo «Pechatnia S. P. Yakovleva».

24. Trudy XXXVII syezda gornopromyshlennikov Yuga Rossii [Proceedings of the XXXVII Congress of Miners of the South of Russia]. (1913). T. 1. Kharkov : Tip. B. Bengis.

25. Fomin, P. I. (1920). Donetskiy basseyn [Donetsk coal field]. Kharkov : B. i.

26. Fomin, P. I. (1924). Gornaya i gornozavodskaya promyshlennost Yuga Rossii [Mining and metallurgical industries of the South of Russia]. T. II. Kharkov : «Khoziaystvo Donbassa».

27. Fomin, P. I. (1908). Kratkiy ocherk istorii syezdov gornopromyshlennikov Yuga Rossii [A Short Essay of the History of Congresses of Mine-Industrialists on the South of Russia]. Kharkov : Tip. i Litogr. M. Zilberberg i S-vya.

28. Khronika [Chronicle]. (1910). Promyshlennost i tirgovlia, 24, 668.

29. Chernomorsko-Baltiyskiy vodnyu put [Black Sea-Baltic Waterway]. (1911). Gorno-zavodskoe delo, 35, 2700-2702.

30. Chernyshev, B. (1912). Chernomorsko-Baltiyskiy vodnyu put v finansovoekonomicheskom osveshchenii [Black Sea-Baltic Waterway in Financial and Economic Presentation]. Russkoye sudokhodstvo, 9, 35-39.

31. Chernyshev, B. (1912). Chernomorsko-Baltiyskiy vodnyu put v finansovoekonomicheskom osveshchenii [Black Sea-Baltic Waterway in Financial and Economic Presentation]. Russkoye sudokhodstvo, 11, 23-29.

32. Shliakhov, O. B. (2003). Sudnovlasnyky i moriaky Azovo-Chornomorskogo baseinu: 90-ti rr. XIX st. - 1914 r.: monografiia [Ship-Owners and Seamen of the Azov-Black Sea Basin: 90-th Years of the 19-th Century - 1914: Monograph]. Dnipropetrovsk : Vyd-vo Dnipropetr. un-tu.

УДК 94(47+57): 323.281-055.2

\section{ДОСВІД ВИЖИВАННЯ ЖІНОК В АКМОЛІНСЬКОМУ ТАБОРІ ДЛЯ ДРУЖИН ЗРАДНИКІВ БАТЬКІВЩИНИ (НА ОСНОВІ ЕГО-СВІДЧЕНЬ)}

\section{Омельченко Поліна}

Основним завданням автора є спроба показати специифічність повсякдення жінок-увя'знених Акмолінського табору для дружин «зрадників Батьківщини», закцентувавши увагу на способах виживання арештанток $i$ на формах подолань горя в таборі. В основі методологічної бази дослідження - загальнонаукові принциипи аналізу та синтезу, метод критичного аналізу джерел, методологія повсякденної історії, а також 